Crisis in the Global Mediasphere 
Also by Jeff Lewis

CULTURAL STUDIES

LANGUAGE WARS: The Role of Media and Culture in Global Terror and Political Violence

BALI'S SILENT CRISIS: Desire, Tragedy and Transition (with Belinda Lewis) 


\section{Crisis in the Global Mediasphere}

Desire, Displeasure and Cultural Transformation

Jeff Lewis 


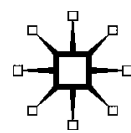

(C) Jeff Lewis 2011

Softcover reprint of the hardcover 1st edition 2011 978-0-230-24742-0

All rights reserved. No reproduction, copy or transmission of this publication may be made without written permission.

No portion of this publication may be reproduced, copied or transmitted save with written permission or in accordance with the provisions of the Copyright, Designs and Patents Act 1988, or under the terms of any licence permitting limited copying issued by the Copyright Licensing Agency, Saffron House, 6-10 Kirby Street, London EC1N 8TS.

Any person who does any unauthorized act in relation to this publication may be liable to criminal prosecution and civil claims for damages.

The author has asserted his right to be identified as the author of this work in accordance with the Copyright, Designs and Patents Act 1988.

First published 2011 by PALGRAVE MACMILLAN

Palgrave Macmillan in the UK is an imprint of Macmillan Publishers Limited, registered in England, company number 785998, of Houndmills, Basingstoke, Hampshire RG21 6XS.

Palgrave Macmillan in the US is a division of St Martin's Press LLC, 175 Fifth Avenue, New York, NY 10010.

Palgrave Macmillan is the global academic imprint of the above companies and has companies and representatives throughout the world.

Palgrave ${ }^{\circledR}$ and Macmillan ${ }^{\circledR}$ are registered trademarks in the United States, the United Kingdom, Europe and other countries.

ISBN 978-1-349-31993-0 ISBN 978-0-230-29770-8 (eBook)

DOI $10.1057 / 9780230297708$

This book is printed on paper suitable for recycling and made from fully managed and sustained forest sources. Logging, pulping and manufacturing processes are expected to conform to the environmental regulations of the country of origin.

A catalogue record for this book is available from the British Library.

Library of Congress Cataloging-in-Publication Data

Lewis, Jeff.

Crisis in the global mediasphere : desire, displeasure and cultural transformation / Jeff Lewis.

p. $\mathrm{cm}$.

Includes bibliographical references.

1. Mass media-Political aspects. 2. Mass media-Social aspects.

3. Mass media and culture. I. Title.

P95.8.L49 2011

$302.23-\mathrm{dc} 22$

2010033962 
To Jack Clancy: friend, mentor, humanist 


\section{Contents}

List of Tables, Figures and Plates viii

Acknowledgements $\quad$ ix

$\begin{array}{ll}\text { Introduction } & 1\end{array}$

1 Imagining the End: Crisis Culture and the Pleasure Economy 14

2 Grand Fraud: New Capitalism, Fantasy and Financial Crisis 52

3 Reckless Desire: Love, Sexuality and Infinite Bliss 93

4 Global Inequalities: Changing World Conditions 131

5 The Shadow and the Fawn: Sustainable Nature and Collapsing Ecologies $\quad 163$

6 Fear and Trembling: The Vicissitudes of Global Terror 193

Conclusion: Visions of the Beginning 220

Notes 225

$\begin{array}{ll}\text { Bibliography } & 227\end{array}$

Index 242 


\section{List of Tables, Figures and Plates}

\section{Tables}

2.1 Growth in national GDP by 2000 international million $\$$ value

2.2 Growth in US public debt in billions of US\$ 79

2.3 Productivity growth rates in key OECD countries 81

4.1 International economic and social development index 142

\section{Figures}

$\begin{array}{llr}1.1 & \text { Crisis model } & 50\end{array}$

3.1 Annual rate of new marriages in OECD countries 104

3.2 Annual rate of divorce in OECD countries 105

\section{Plates}

1.1 Inca ruins in the Andes Mountains. Like the Maya, the Incas were a powerful civilization which engaged in ritual human sacrifice as a way of appeasing their gods

2.1 The rise of Western European industrial trading systems as represented in the great Victorian trading houses on the River Thames in London

3.1 A Muslim family bears the rainbow flag in the 2009 Gay Pride celebrations in New York

4.1 Family life in the South Sudan, Africa

6.1 Mediating Ground Zero-now a major tourist attraction in New York

6.2 Armaments gathered as a grave monument in Afghanistan, 2009 


\section{Acknowledgements}

My deepest gratitude to Belinda Lewis for her conversation, support, friendship and brilliant editing. Thanks also to Sian Lewis and Jay Lewis who helped me clarify the underlying thesis of this book, and whose support and encouragement has once again been immeasurable. Thanks to Jay for research support, especially for Chapters 2 and 3; thanks to Sian for support on Chapters 4 and 5.

I am indebted to my colleagues in the Human Security Program at RMIT-especially Paul James, John Handmer and Damian Grenfell. Thanks to Lauren Murray, Alan Cumming, Tony Dalton and Kim Humphery. Thanks to colleagues in the School of Media and Communication-especially Chris Hudson and Sharenjeev Johal whose scholarly interests and good humour are an inspiration. I am also grateful for the financial support provided by the School of Media and Communication under Lauren Murray and RMIT University more generally. Thanks to other colleagues for their support and interestI Nyoman Darma Putra, Chris Rojek and Mila Steele. Many thanks to my graduate students, particularly Dr Diana Bossio, Dr Kristen Sharp and Prayudi Ahmed. Special thanks to Stephen Gaunson who has made an invaluable contribution to this book.

Thankyou to Christabel Scaife and Catherine Mitchell at Palgrave Macmillan.

Thankyou for the use of photographs-Belinda Lewis (Plates 3.1 and 6.1), George Paterson (Plate 1.1) and Simon Richards (Plates 4.1 and 6.2).

Many thanks to Terry Batt for the use of his extraordinary painting 'Business as Usual' on the cover of this book. 